\author{
С.В. Петров
}

Федеральное государственное бюджетное учреждение
«27 Научный центр» Министерства обороны Российской Федерации,
105005, Российская Федерация, г. Москва, Бригадирский переулок, д.13

Поступила 03.11.2017 г. Принята к публикации 07.03.2018 г.

Последний российский химический снаряд уничтожен 27 сентября 2017 г. на специальном предприятии в удмуртском поселке Кизнер. Уничтожение химического оружия (XO) начато в условиях распада СССР, смены политической формации и последовавшего за этим обрушения экономики. Исторической вехой на пути выполнения Россией международных обязательств в области химического разоружения стало Постановление Правительства Российской Федерации от 21 марта 1996 г. № 305, утвердившее Федеральную целевую программу «Уничтожение запасов химического оружия в Российской Федерации». Благодаря научным и технологическим наработкам, сделанным еще в советское время, а также чрезвычайным усилиям и таланту специалистов войск РХБ защиты Вооруженных Сил Российской Федерации, Федерального управления по безопасному хранению и уничтожению химического оружия и ряда гражданских научно-исследовательских организаций ее удалось завершить на три года раньше намеченного срока. Для уничтожения ХО использовалась технология двухстадийной химической нейтрализации, которая подвергалась технической адаптации в зависимости от типа и способа хранения ХО. Было построено 7 специальных предприятий по уничтожению XО - в пос. Горный (Саратовская область), в г. Камбарка и пос. Кизнер (Удмуртская Республика), в пос. Марадыковский (Кировская обл.), в г. Щучье (Курганская обл.), в пос. Леонидовка (Пензенская обл.) и в г. Почеп (Брянская обл.). Всего уничтожено 40 тыс. т ОВ. Досрочное выполнение Федеральной программы сэкономило для страны значительные денежные средства и избавило население обширных территорий, примыкавших к объектам хранения, от серьезных угроз в случае аварий и происшествий на них.

Ключевые слова: химическое оружие; СССР; конвенция; уничтожение; Федеральное управление по безопасному хранению и уничтожению химического оружия (ФУ БХУХО); РХБЗ; боеприпасы; утилизация; комплекс уничтожения аварийных специзделий (КУАСИ).

Библиографическое описание: Петров С.В. Как создавался фундамент государственной программы уничтожения химического оружия в России // Вестник войск РХБ защиты. 2018. T. 2. № 1. C. $24-36$.

В сентябре 2017 г. успешно завершилась программа уничтожения химического ору-

жия в России, обошедшаяся нашей стране в 316 млрд рублей (далее - программа) $)^{1,2}$. Со вре-

\footnotetext{
1 Российская Федерация уничтожит последний химический боеприпас 27 сентября (20 сентября 2017 г.). URL: https://iz.ru/648248/2017-09-20/rf-unichtozhit-poslednii-khimicheskii-boepripas-27-sentiabria (дата обращения: 18.10.2017).

227 сентября в удмуртском поселке Кизнер торжественно уничтожили последний российский химический снаряд. Это событие стало завершением масштабной, более чем 20-летней работы по уничтожению арсена- 
менем те, кому положено, подведут общие итоги этой гигантской и чрезвычайно опасной работы. Мне же, как человеку, стоявшему у истоков этой проблемы, хочется рассказать, как это было в начале пути, до того, как из состава войск радиационной, химической и биологической защиты (РХБЗ) была выделена значительная, высококвалифицированная в сфере обращения с реальным химическим оружием часть специалистов, и было образовано Федеральное управление по безопасному хранению и уничтожению химического оружия (ФУ БХУХО). Тем самым была утрачена возможность повышения профессиональных качеств офицерского состава за счет ротации кадров, занимающихся выполнением других задач РХБ защиты, с теми, кто получил практику работы с реальным химическим оружием, т.е. была потеряна возможность обучения большого количества офицеров практической работе. Кстати, в армии США химическое оружие из состава Министерства обороны не выводилось.

Уничтожение химического оружия в России имеет особенности, оказавшие существенное влияние на ход реализации программы, сроки ее осуществления и объем морально-психологических издержек воинских и научно-исследовательских контингентов, которые были привлечены к решению этой задачи.

В то время тяжким бременем на государство легла непосильная тяжесть выполнения различных разоруженческих задач. Здесь и вывод войск из стран Восточной и Центральной Европы, и ликвидация ракетного вооружения средней и малой дальности, и утилизация самолетов стратегической авиации, и уничтожение химического оружия, и многое другое. Такой нагрузки не выдержало бы никакое другое государство даже со здоровой экономикой.

Армии приходилось решать сложнейшую задачу. Была частично демонтирована приемлемая для новых условий законодательная база. Кардинально изменился характер взаимодействия с местными органами власти и работы с общественностью. Обыкновенная демократия переросла в демократию «майданного» типа. Bсе это необходимо было преодолеть.

Следует сказать, что работа велась не на пустом месте. Многие страны уже занимались утилизацией химического оружия, но очень своеобразно. Например США и Великобритания просто затопили в Датских проливах тысячи тонн трофейного немецкого химического оружия. По нынешним воззрениям, технология варварская, но она была в те времена научно обоснована.
Однако вооруженные силы СССР уже с середины 1970-х гг. плотно занялись разработкой современных технологий утилизации появившихся аварийных химических боеприпасов, небольшое количество которых было выявлено на арсеналах и хранилось в герметичных футлярах.

Эта работа была успешно завершена разработкой в 1980 г. первого комплекса КУАСИ (комплекс уничтожения аварийных специзделий), в основу функционирования которого была положена двухстадийная технология утилизации отравляющих веществ нервно-паралитического действия. Эта технология была реально продемонстрирована участникам женевского переговорного процесса по запрещению химического оружия в октябре 1987 г. во время показа им типовых образцов химических боеприпасов Советской Армии в Шиханах (Саратовская область).

В СССР по заказу Министерства обороны было произведено более 1,5 десятков КУАСИ, которые были поставлены на арсеналы ракетных войск, артиллерии и ВBC, чем была закрыта проблема утилизации аварийных химических боеприпасов.

В 1995 г. по решению начальника Генерального штаба ВС РФ генерала армии М.П. Колесникова на базе Саратовского высшего военно-инженерного училища войск РХБ защиты и научного центра в г. Эджвуде (Edgewood Arsenal, США) был успешно проведен совместный эксперимент по оценке этой технологии. Она получила положительное заключение по итогам международной экспертизы.

Разработка и совершенствование технологий уничтожения химического оружия в СССР и Российской Федерации не прекращались вплоть до 1998 г., когда окончательно были выбраны технологии утилизации люизита (щелочной гидролиз с последующим электролизом), иприта и ипритно-люизитных смесей (двухстадийная с последующим битумированием реакционных масс). А совершенствование технологических подходов к утилизации ОВ нервно-паралитического действия продолжалось и после 1998 г.

Однако вернемся к истокам. В 1982 г. страны социалистического блока внесли в международный комитет по разоружению в Женеве проект Конвенции о полном запрещении химического оружия, а в 1985 г. СССР, ГДР, ФРГ, Чехословакия, Норвегия, Дания и Нидерланды выступили с инициативой о создании в Центральной Европе зоны, свободной от химического оружия. М.С. Горбачев повел это мирное наступление под лозунгом: «Встретим XXI век без химического оружия».

ла химического оружия в нашей стране. URL: https://sm-news.ru/news/analitika/proshchay-oruzhie-v-rossiizavershilas-programma-khimicheskogo-razoruzheniya/ (дата обращения: 18.10.2017). 
Соединенные Штаты Америки, чей химический арсенал был старше советского на 25-30 лет, и значительная часть которого находилась в предаварийном состоянии, встретили эти инициативы аплодисментами, поощряя руководство СССР к форсированию решения этих чрезвычайно затратных намерений.

4 ноября 1985 г. вышло постановление ЦК КПСС о строительстве первого опытнопромышленного объекта уничтожения химического оружия, в соответствии с которым Министерство обороны СССР получило задачу выбора места для стро-

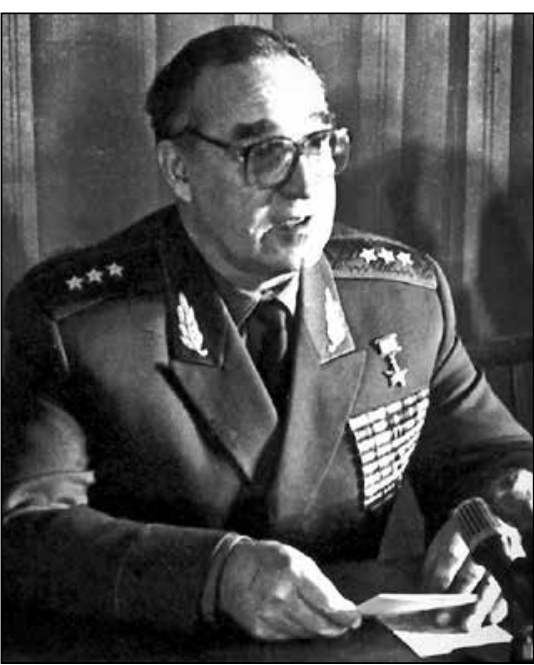

Генерал-полковник В.К. Пикалов

После тщательного изучения всех аспектов проблемы начальником химических войск генерал-полковником В.К. Пикаловым был согласован с руководством Куйбышевской области и подписан акт выбора участка под строительство объекта (под шифром 1212) в 12 км юго-западнее г. Чапаевск (рисунок 1). Акт был утвержден начальником Генерального штаба маршалом Советского Союза С.Ф. Ахромеевым.

Строительство развертывалось на землях базы химических войск, командовал коительства и развертывания работ по его созданию.

Следует отметить, что весь комплекс мероприятий, направленных на выполнение этой уникальной задачи, с самого начала осуществлялся в рамках существовавшей в то время нормативной законодательной базы. большой опыт организации масштабных строительных работ полковник В.К. Соловьев, помощником по строительству у которого был капитан А.Б. Ещеулов. Контроль за строительством осуществлял инженерно-строительный отдел УНХВ во главе с полковником Ю.В. Орловым, научно-техническое сопровожде-

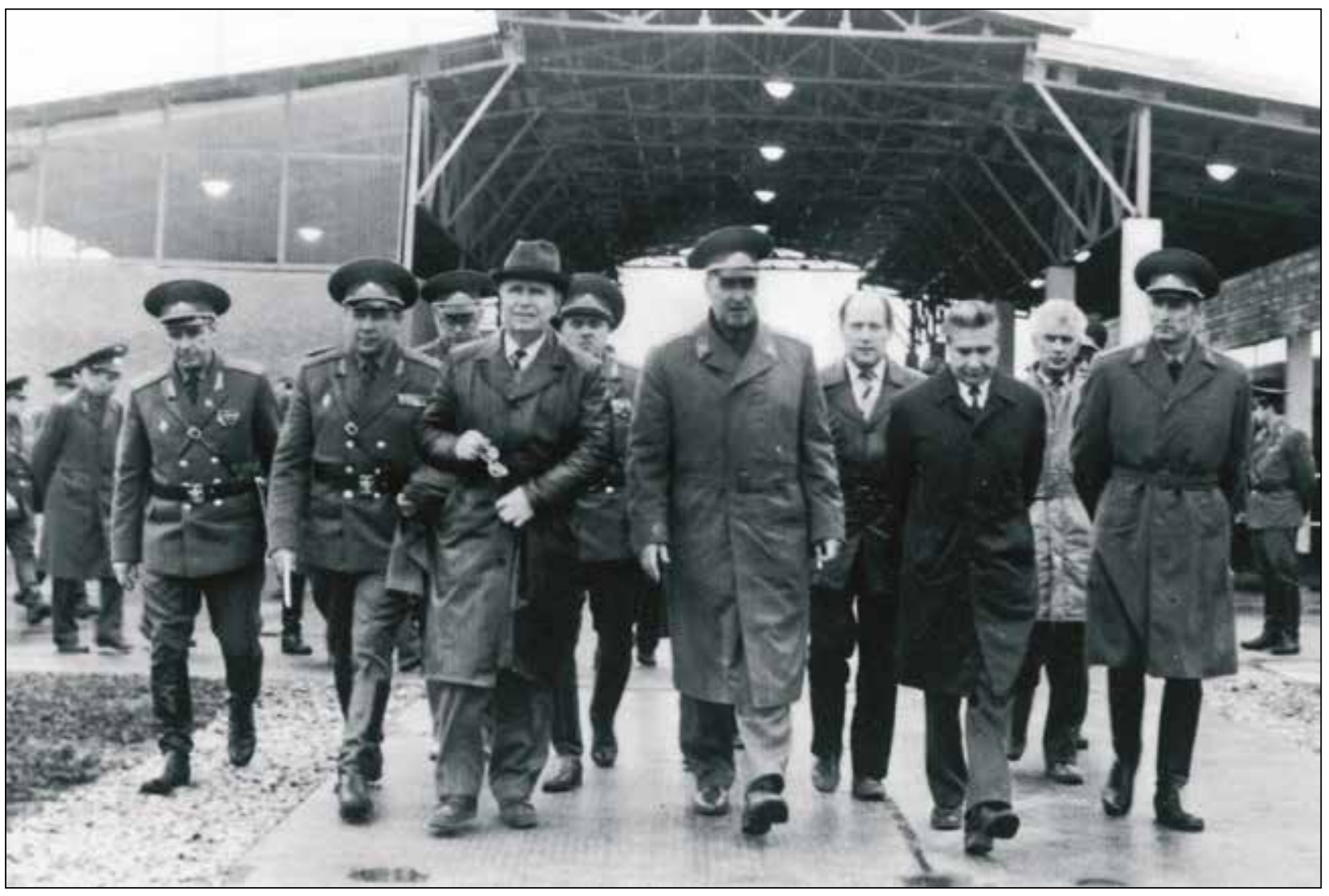

Рисунок 1 - Генерал-полковник В.К. Пикалов проверяет ход строительства объекта по уничтожению химического оружия под чапаевском (объект 1212)

\footnotetext{
1 Фотография из книги «Федеральное управление по безопасному хранению и уничтожению химического оружия. 20-летию посвящается». М., 2012.
} 
ние строительства обеспечивал НИО войск РХБЗ ВС РФ.

Для проектирования объекта была создана кооперация научно-исследовательских и проектных институтов, включавшая в себя государственный научно-исследовательский институт органической химии и технологии и государственный проектный институт специального строительства MO CCCP.

Строительство предприятия проводило Главное управление специального строительства Минобороны, монтаж промышленного и специального технологического оборудования осуществлял Минмонтажспецстрой СССР. Монтаж специфичного технологического оборудования и его наладка были поручены Минхимпрому СССР.

В 1986 г. была разработана и утверждена проектно-сметная документация для начала строительства, а в августе этого же года в район строительства были передислоцированы 4 военно-строительных отряда из состава Дальневосточного военного округа. В кратчайшие сроки они осуществили обустройство, создали строительную базу и приступили к выполнению главной задачи. Мне - в то время первому заместителю начальника химических войск - было поручено сопровождение строительства завода, впрочем, как и всех других объектов строительства в подчиненных частях и учреждениях (рисунок 2).

Преодолевая объективные и субъективные трудности, кооперация проектировщиков, строителей и монтажников успешно воздвигла красавец-завод с жилым городком, отвечавшим самым высоким социальным стандартам, с дублированными источниками электроэнергии, газо- и водоснабжением, индивидуальной системой очистки бытовых отходов и канализации. Летом 1988 г. было опробовано оборудование на инертных средах и объект был подготовлен к пуску.

Тем временем СССР продолжал выдвигать мирные инициативы на фронте химического разоружения. В апреле 1987 г. М.С. Горбачев объявил о прекращении в одностороннем порядке производства химического оружия. В октябре этого же года мы осуществили показ типовых его образцов участникам переговоров о запрещении химического оружия в Женеве с демонстрацией реального уничтожения на комплексе КУАСИ снаряженной зарином 250-кг авиационной бомбы. В декабре МИД СССР объявил о том, что Советский Союз имеет запасы химического оружия, не превышающие по весу OB 50 тыс. т, никогда не применял его и не передавал другим странам.

В 1988 г. МО СССР, 27 НЦ химических войск в кооперации с другими министерствами и ведомствами, главным образом Минхимпромом, была завершена разработка концепции страны по подготовке к возможному вступлению в действие Конвенции о запрещении разработки, производства, накопления химического оружия и о его уничтожении. В апреле этого же года она была утверждена решением Государственной комис-

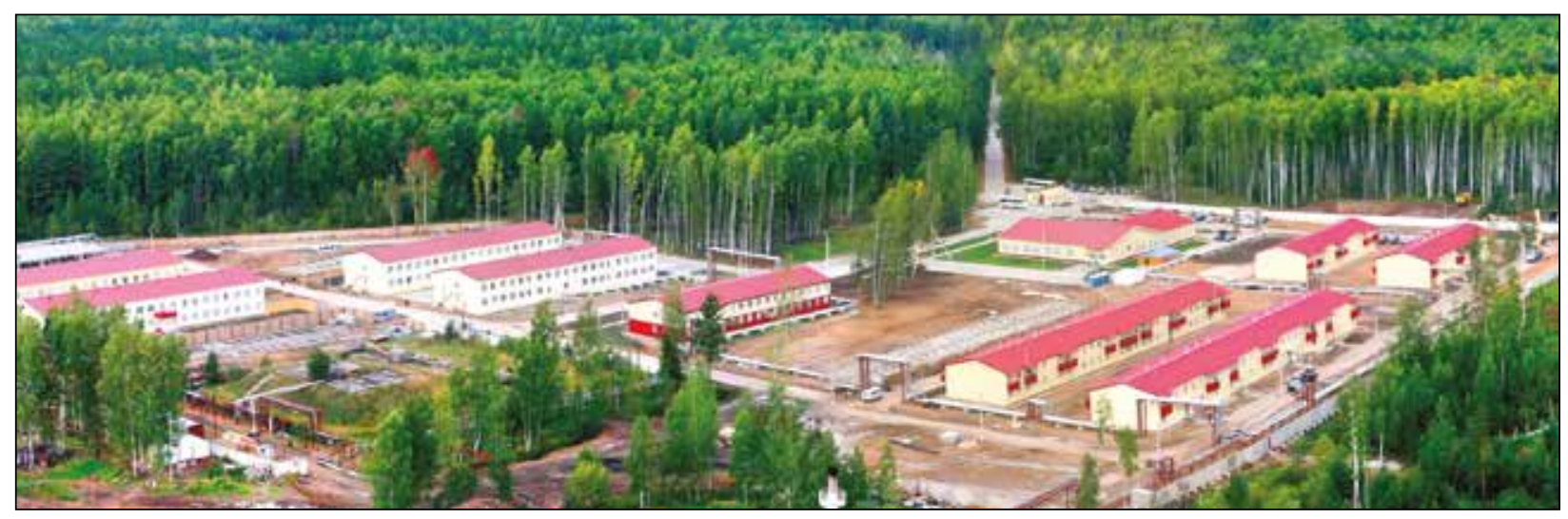

Рисунок 2 - Строительство вахтового городка ${ }^{1}$

\footnotetext{
1 Фотография из книги «Федеральное управление по безопасному хранению и уничтожению химического оружия. 20-летию посвящается». М., 2012.
} 


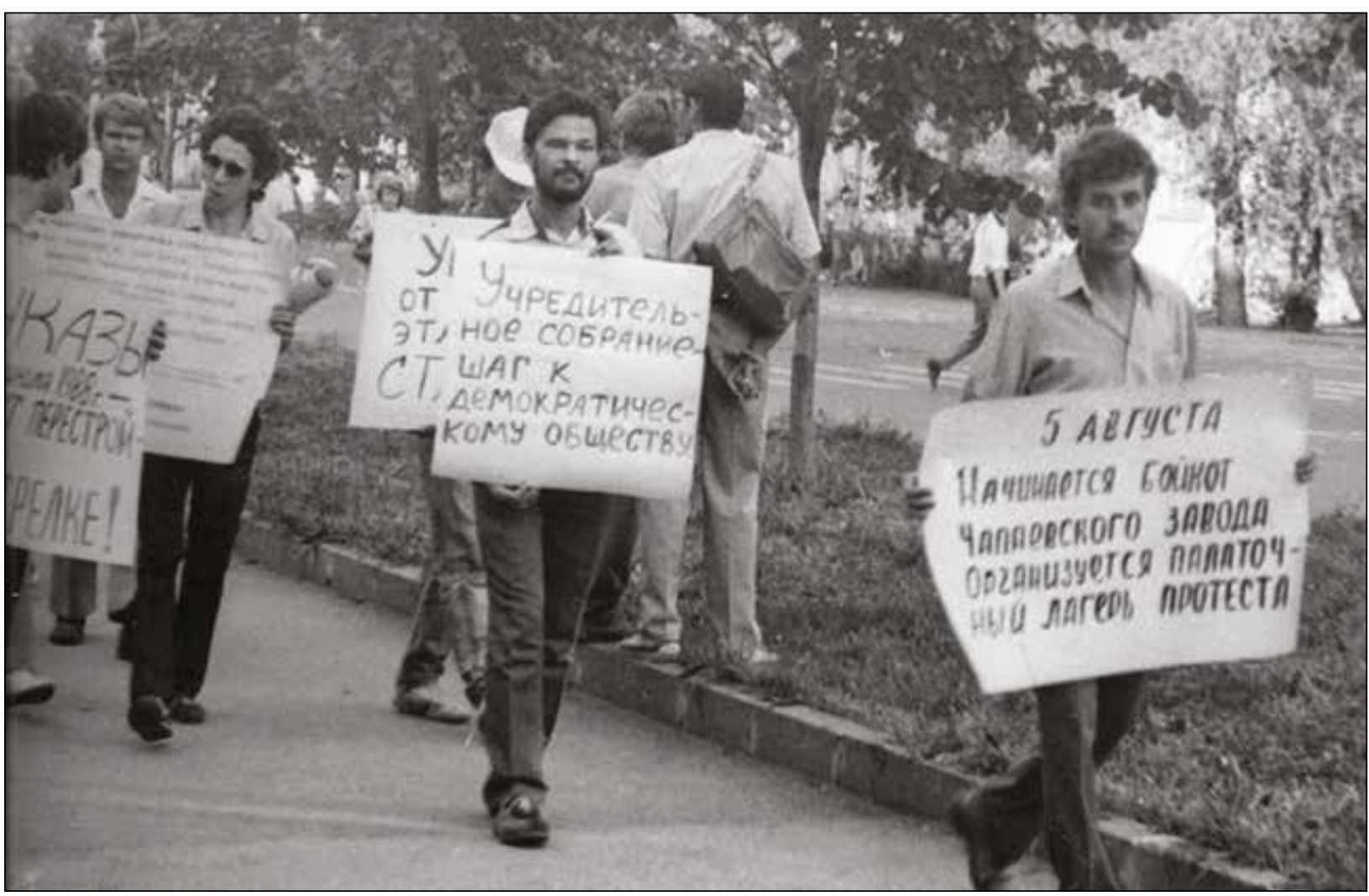

Рисунок 3 - Акция протеста в Куйбышеве (Самара) в августе 1989 г. против строительства завода по уничтожению химического оружия. Обратите внимание на плакат у человека в центре фотографии. Там речь идет о замене органов советской власти неким неконституционным образованием - учредительным собранием. Протесты против строительства завода под Чапаевском были частью мероприятий по разрушению СССР 1

\footnotetext{
Фотография с интернет-ресурса SAMARA TODAY.RU. URL: http://samaratoday.ru/news/252549 (дата обращения 12.10.2017).

сии Совмина СССР по военно-промышленным вопросам.

Химическое оружие СССР должно было уничтожаться на четырех объектах, которые необходимо было создать в г. Чапаевск Куйбышевской области, п. Горный Саратовской области, в г. Камбарка Удмуртской республики и г. Новочебоксарск Чувашской республики (перепрофилирование объекта по производству химического оружия).

В Чапаевске к тому времени уже сформировалось ядро протестного движения против пуска объекта уничтожения химического оружия. Бесконечные пикеты, митинги, палаточные городки мешали работе и представляли собой реальную угрозу безопасности объекта и всего Чапаевского района (рисунок 3).

Наконец, когда среди протестующих возникла идея провести всеобщую забастовку в Куйбышевской области, была сформирована правительствен-

ная комиссия во главе с авторитетным ученым, академиком Николаем Павловичем Лавровым, которая встретилась с представителями общественности во дворце культуры г. Чапаевск. Многочисленные выступления экспертов с доказательствами безопасности объекта никого не убедили. Толпа ревела, осыпая членов комиссии оскорблениями и требуя закрытия предприятия. В результате комиссия пришла к выводу о невозможности пуска завода по социально-политическим условиям ${ }^{3}$.

К тому времени в войсках РХБЗ МО СССР Саратовское военное училище уже было нацелено на подготовку кадров для решения задачи утилизации химического оружия. Чапаевский объект было предложено использовать как учебно-тренировочный центр училища для получения выпускниками практики работы на профильном предприятии с использованием инертных сред. Это предложение было реализовано распоряжением Совмина СССР.
}

\footnotetext{
3 Горячие бомбы «холодной войны» // Российская газета. Федеральный выпуск № 3439 (0) от 26.03 .2004 г. URL: https://rg.ru/2004/03/26/himoruzhie.html (дата обращения 12.10.2017).
} 


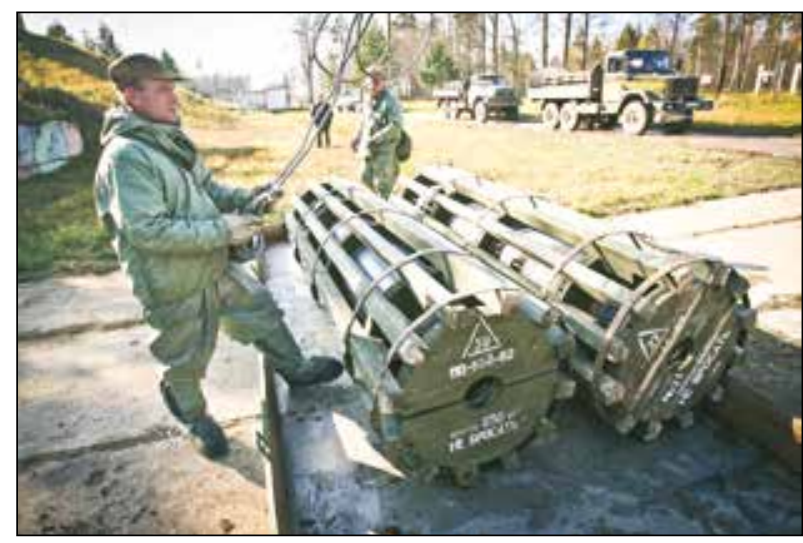

Рисунок 4 - Погрузка химических авиачонных боеприпасов ${ }^{1}$, предназначенных для уничтожения

Фотография из книги «Федеральное управление по безопасному хранению и уничтожению химического оружия. 20-летию посвящается». М., 2012.

Однако задачуликвидациихимическогооружия с МО СССР никто не снимал. В этих условиях необходимобылоискатьновыепути решенияэтой проблемы (рисунки 4, 5). По предложению МО СССР постановлением Политбюро ЦК КПСС в декабре 1989 г. на базе 27 Научного центра решением ГВПК Совмина СССР и при участии АН СССР была создана межведомственная рабочая группа из представителей восемнадцати министерств и ведомств, которой было поручено в максимально сжатые сроки разработать «Государственную программу уничтожения химического оружия в СССР». Непосредственное руководство разработкой программы осуществлял Игорь Борисович Евстафьев, обладающий высочайшей трудоспособностью, научной компетентностью и незаурядными организаторскими способностями. Рассматривалось несколько вариантов строительства объектов утилизации ХО с размещением их на островах Новая земля и в других малонаселенных районах, но они были связаны с необходимостью перевозки большого количества боеприпасов, строительством железных дорог, погрузочно-разгрузочных терминалов, что значительно удорожало реализацию программы, а в связи с нараставшей в стране перестроечной анархией и небезопасно. К тому же было очевидно, что «общественность» не допустит перевозки миллионов единиц химических боеприпасов с арсеналов их хранения в другие регионы. Поэтому наиболее глубоко и детально был рассмотрен вариант ликвидации химического оружия в местах его хранения. Концепция реализации программы на четырех объектах была отклонена не только из-за протестов в Чапаевске,

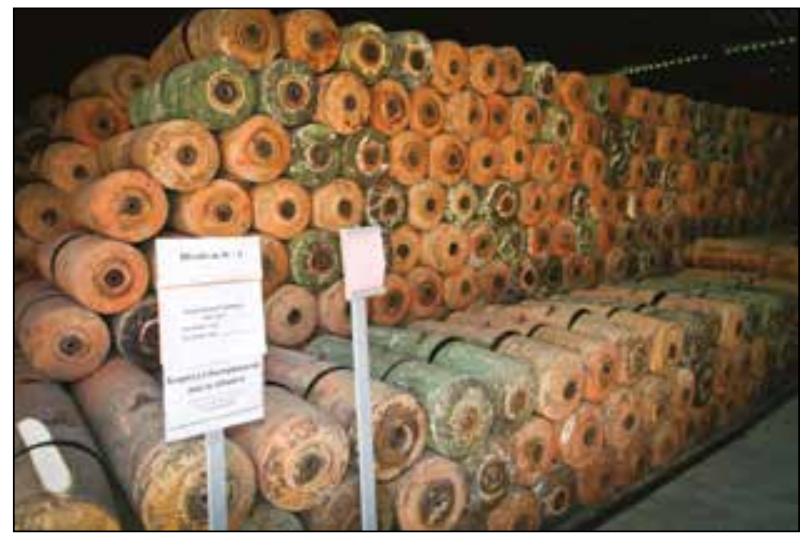

Рисунок 5 - Обезвреженные детали корпусов авиачионных химических боеприпасов ${ }^{1}$

\footnotetext{
Фотография из книги «Федеральное управление по безопасному хранению и уничтожению химического оружия. 20-летию посвящается». М., 2012.
}

но и в связи с решением правительства Чувашской АССР о недопущении ввоза ХО на территорию Чувашии.

Программа была разработана в установленные сроки и содержала научно обоснованные предложения о порядке выбора мест размещения объектов, их проектирования, строительства и функционирования. Были определены объемы финансирования и организационно-кадрового обеспечения, исходя из сроков решения задачи уничтожения ХО страны, вытекавших из разрабатываемых международных соглашений.

Большое внимание в программе уделялось порядку взаимодействия с местными органами власти и общественностью в регионах строительства объектов, а также безопасности населения.

Специально созданной постановлением Госкомприроды СССР комиссией была осуществлена экологическая экспертиза проекта программы и рекомендовано остановиться на варианте строительства предприятий в местах хранения химического оружия. Проект программы в установленный срок был представлен на рассмотрение в Верховный Совет СССР, но там каких-либо решений по этому поводу принято не было.

1 июня 1990 г. президентами СССР и США было подписано соглашение «Об уничтожении и непроизводстве химического оружия и о меpax по содействию многосторонней Конвенции о запрещении химического оружия ${ }^{4}$, а у нас еще не было утвержденной программы. И только в феврале 1991 г. рассмотрение проекта программы в комитетах и комиссиях Верховного Совета СССР было завершено. Но это был еще не конец, хотя при этом и была решена одна из важней-

\footnotetext{
4 Соглашение между СССР и США об уничтожении и непроизводстве химического оружия и о мерах по содействию многосторонней конвенции о запрещении химического оружия (1990г.). URL: http://arhiv.inpravo. ru/data/base304/text304v479i632.htm (дата обращения: 21.10.2017).
} 
ших задач. Кабинет министров СССР получил рекомендации при реализации программы выделять на развитие инфраструктуры регионов, где хранилось ХO, и где оно должно было уничтожаться, не менее $10 \%$ от ассигнований, отпущенных проектом на строительство, как это и было предусмотрено программой. Это решение сыграло весьма позитивную роль на весь срок решения задачи уничтожения.

Проект государственной программы был доработан и в мае 1991 г. представлен на утверждение в Кабинет Министров СССР, который вскоре был упразднен и вопрос снова повис в воздухе, а тут грянул Августовский «путч» и вслед за этим прекратил свое существование СССР, правопреемницей которого стала Российская Федерация.

В феврале 1992 г. был создан Комитет по конвенционным проблемам химического и биологического оружия при Президенте Российской Федерации ${ }^{5}$ который сразу активно включился в решение вопроса уничтожения ХО. Главной заботой Комитета было возложить на себя функции государственного заказчика при реализации Госпрограммы уничтожения химического оружия. При этом была развернута активная деятельность в области доработки программы, которая стала называться комплексной. Очень активно Комитет занимался вопросами внешнеполитической деятельности, направленной на поиски спонсоров программы. Однако в целом функционирование этой организации сковывало усилия Министерства обороны Российской Федерации по приданию планового характера взаимодействию всех государственных структур, привлекавшихся к реализации Госпрограммы. Через несколько лет Комитет прекратил свое существование.

Несмотря на огромные трудности, Министерство обороны Российской Федерации и, в частности, Управление начальника войск (УНВ) РХБЗ продолжали наращивать усилия по подготовке к практическому уничтожению ХО. В штат УНВ РХБЗ была введена должность заместителя начальника по уничтожению химического оружия, им стал в то время генерал-майор Ю.В. Тарасевич, а в августе этого же 1992 г. в составе УНВ было создано Управление ликвидации химического оружия, ко- торое возглавил полковник В.К. Соловьев.

ГосНИИОХТ приступил к разработке технико-экономического обоснования для строительства терминала расснаряжения люизита в г. Камбарка.

13 января 1993 г. Россия подписывает «Конвенцию о запрещении разработки, производства, накопления и применения химического оружия и о его уничтожении» [1]. И хотя она была ратифицирована Федеральным собранием Государственной Думы Российской Федерации лишь в 1997 г., факт ее подписания подхлестнул правительство страны к осуществлению подготовительных работ для реализации требований Конвенции.

作 рации распоряжением Совмина Правительства Российской Федерации назначается государственным заказчиком выполнения этих работ.

Управление ликвидации химического оружия активизировало работу по выбору технологий. Было организовано проведение экспертной оценки четырех технологий уничтожения люизита. Из них выбраны для реализации две.

УНВ РХБ3 в это же время на рассмотрение Министра обороны был внесен проект указа Президента России по данному вопросу, который и был подписан Президентом в феврале 1994 г. Указ этот носит наименование: «О порядке привлечения воинских частей и учреждений ВС РФ для проведения мероприятий по реализации международных обязательств России в области химического разоружения» [2]. Этим указом для решения задач уничтожения ХО России Министерству обороны выделялась численность 10,5 тыс. человек военнослужащих и гражданского персонала вне норм численности Вооруженных Сил. Этот факт сыграл выдающуюся роль при определении штатных структур и численности строящихся и находящихся в эксплуатации объектов уничтожения химического оружия.

В это же время было принято решение «Об организации работ по созданию объекта по уничтожению запасов отравляющих веществ, хранящихся на территории Саратовской области» [3]. Этому предшествовала большая работа по согласованию проблемы с губернатором Саратовской области Д.Ф. Аяцковым и ее правительством.

\footnotetext{
О создании Комитета по конвенциальным проблемам химического и биологического оружия при Президенте Российской Федерации. Указ Президент РФ № 160 от 19 февраля 1992 г. URL: http://www. businessrealty.ru/pravo/DocumShow_DocumID_40225.html (дата обращения: 12.10.2017).
} 
Но и тогда еще не было основополагающих документов для решения масштабной задачи ликвидации всех запасов химического оружия. Наконец, в начале 1995 г. в УНВ РХБЗ был подготовлен проект указа «О подготовке Российской Федерации к выполнению международных обязательств в области химического разоружения» [4], который и был благополучно подписан Президентом страны.

В указе предусматривалось: химическое оружие уничтожить в местах его хранения; функции государственного заказчика возложить на Министерство обороны Российской Федерации; Министерству обороны Российской Федерации совместно с заинтересованными органами исполнительной власти предлагалось разработать Федеральную целевую программу «Уничтожение запасов химического оружия в Российской Федерации» [5].

Только через пять лет после разработки первого варианта программы, наконец, были приняты основополагающие принципы решения проблемы уничтожения.

Задача, поставленная Президентом, была выполнена совместными усилиями специалистов Министерства обороны Российской Федерации и целого ряда проектных и научно-исследовательских институтов. Программой предусматривалось не только формирование тактики и стратегии уничтожения химического оружия в России, но и решение целого ком-

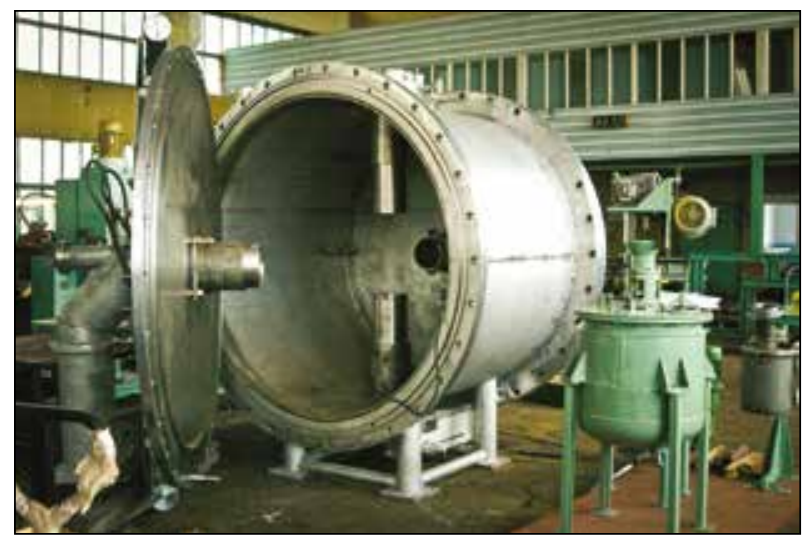

Рисунок 6 - Экспериментальный комплекс обезвреживания изделий сложной конструкции

\footnotetext{
Фотография из книги «Федеральное управление по безопасному хранению и уничтожению химического оружия. 20-летию посвящается». М., 2012.
}

плекса задач, связанных с созданием законодательной и технической базы уничтожения $\mathrm{XO}$; обеспечение безопасности процесса и охраны окружающей среды (рисунки 6, 7); контроль за состоянием здоровья персонала объектов и населения регионов их размещения; вопросы кадрового обеспечения; развитие инфраструктуры регионов, строительства предприятий утилизации ХО и целый ряд других вопросов, выстраданных коллективом разработчиков Федеральной программы в сумятице перестроечных и постперестроечных лет.

В 1996 г. Федеральная программа была утверждена правительством Российской Федерации.

В 1996 г. на должность начальника Управления ликвидации ХО был назначен генерал-майор В.П. Капашин, к концу года он стал заместителем начальника войск РХБЗ по уничтожению химического оружия и этот факт, несомненно, был одной их самых больших моих кадровых удач.

К этому моменту я уже достаточно хорошо изучил морально-деловые качества своего нового заместителя. В 1990 г. было расформировано Главное командование войск Западного направления, где Валерий Петрович исполнял обязанности начальника химических войск, и я, будучи уже знакомым со стилем работы этого талантливого офицера, предложил ему должность начальника 23 Государственного специального научно-исследовательского полигона и не ошибся.

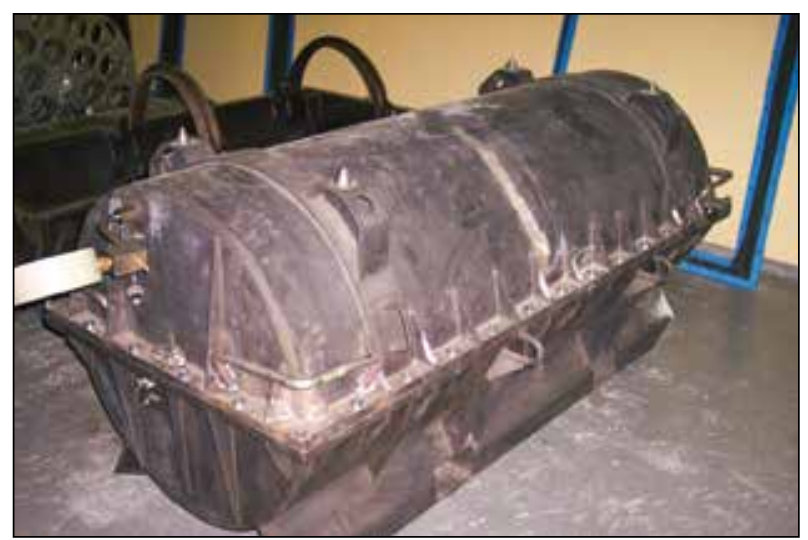

Рисунок 7 - Герметичный контейнер ${ }^{7}$

Фотография из книги «Федеральное управление по безопасному хранению и уничтожению химического оружия. 20-летию посвящается». М., 2012. 
В кратчайшие сроки нам удалось эвакуировать с места дислокации огромные материальные ценности и весь персонал учреждения - офицеров, их семьи, солдат, сержантов и служащих. Эвакуация была осуществлена через две государственные границы.

Потом у него была служба в Дальневосточном военном округе, где Валерий Петрович стал генерал-майором. И вот он - мой заместитель. В те годы всем было нелегко служить и работать, но с приходом В.П. Капашина я ощутил заметное физическое облегчение. Жесткий, требовательный, фанатично преданный делу и долгу генерал сам трудился, не покладая рук, и требовал того же от подчиненных.

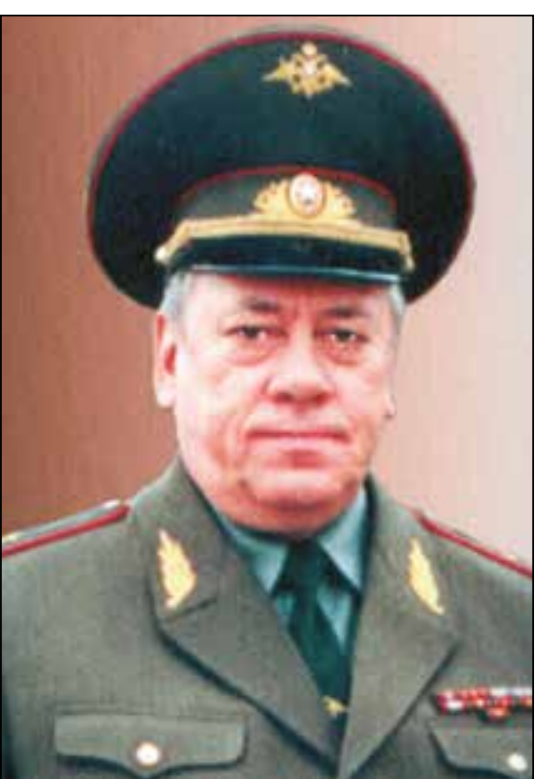

Генерал-майор В.А. Ульянов частую велось за счет средств подрядчика под честное слово Валерия Петровича, конечно же, при полной моей поддержке. Единственным оправданием для нас было то, что не дачи строили себе, а выполняли задачу, взятую на себя государством (рисунок 8).

В 1997 г. решением начальника Генерального штаба генерала армии М.П. Колесникова в состав войск РХБЗ были включены пять арсеналов хранения химического оружия - два из ГРАУ (Главное ракетно-артиллерийское управление) и три из состава ВВС. В центральный аппарат начальника войск РХБЗ вошли офицеры ГРАУ и ВBC, ответственные за хранение химического оружия на соответствующих арсеналах. Все они организационно влились в состав Управления ликвидации химического оружия, которое возглавлял в то время генерал-майор В.А. Ульянов.

Таким образом, в Вооруженных Силах обустройству строительных организаций и сс данию первых объектов социальной и инженерной инфраструктуры для объектов уничтожения ХO в п. Горный и г. Камбарка. Строительство за-

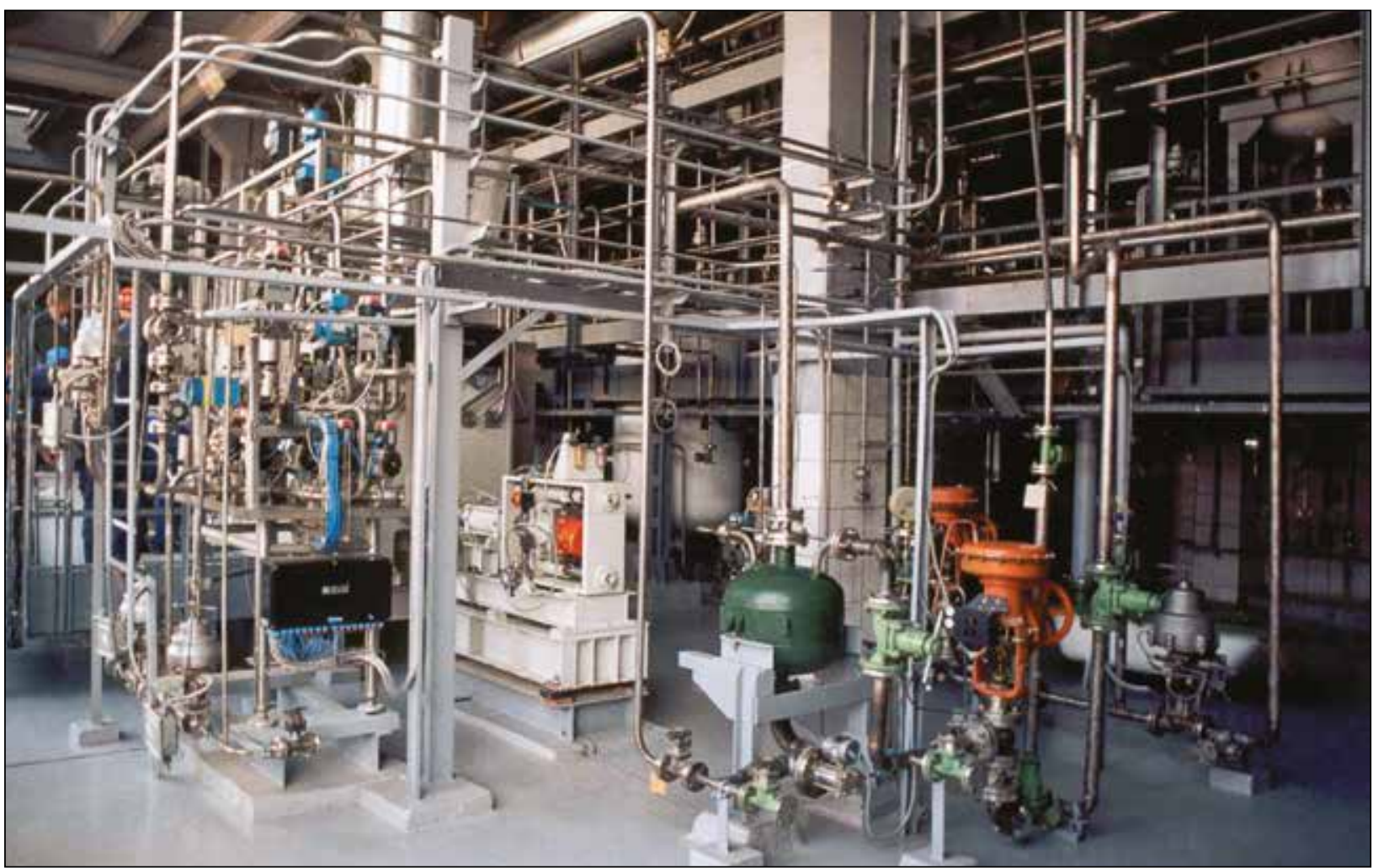

Рисунок 8 - Линия по уничтожению люизита на объекте «Горный» (Саратовская область)

\footnotetext{
Фотография из книги «Федеральное управление по безопасному хранению и уничтожению химического оружия. 20-летию посвящается». М., 2012.
} 
The Start of the State Program of CW Destruction in Russia

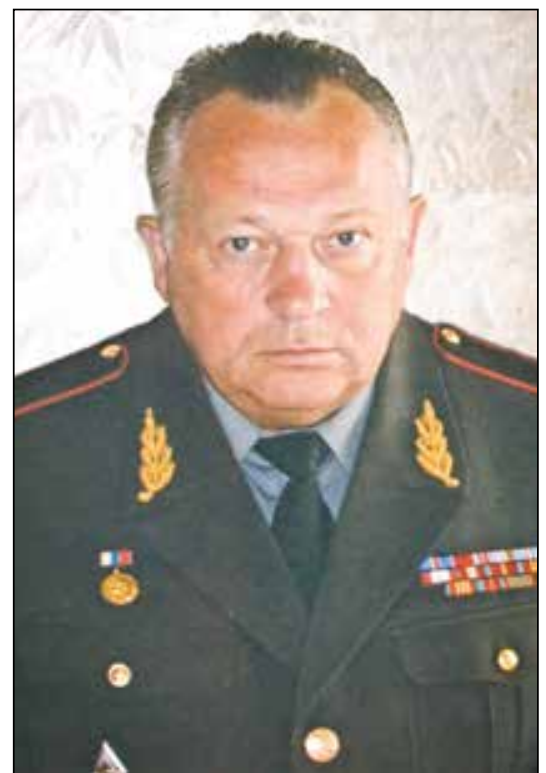

Генерал-майор В.Н. Орлов

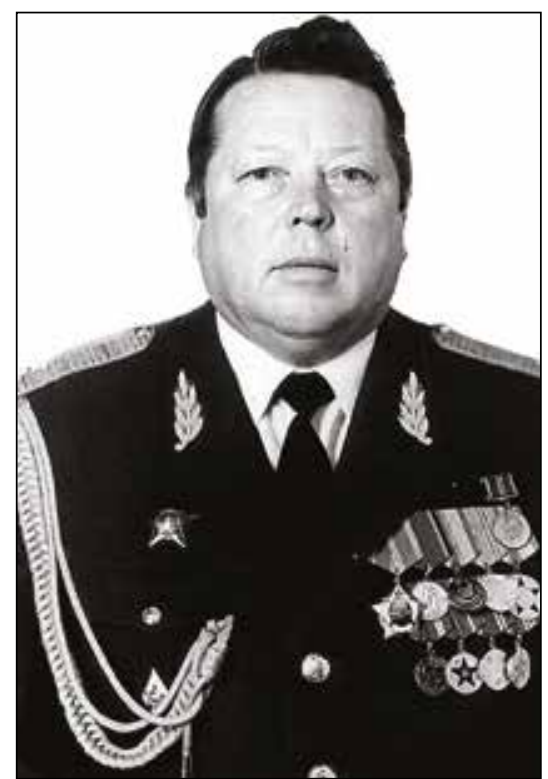

Генерал-лейтенант Ю.Н. Корякин

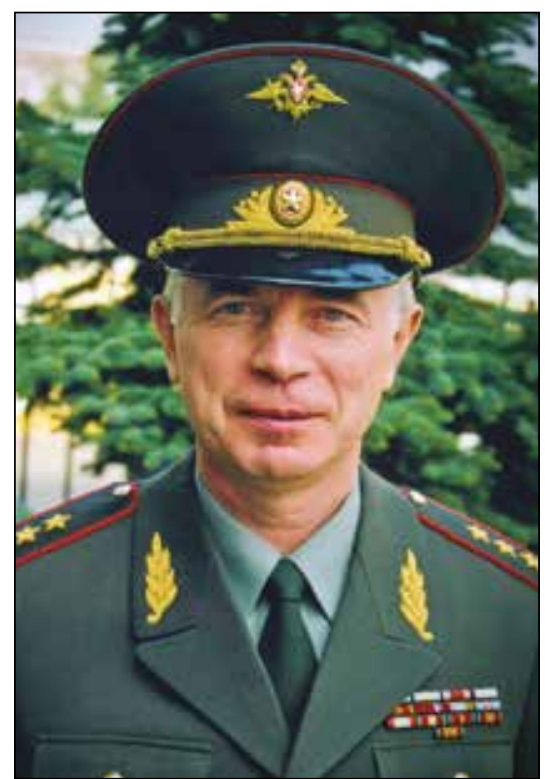

Генерал-полковник В.И. Холстов ние единой системы руководства по обеспечению безопасного хранения и уничтожения химического оружия.

Это позволило широким фронтом развернуть разработку технико-экономических обоснований для создания объектов уничтожения химического оружия на принятых в состав войск РХБЗ пяти арсеналах.

Министерство обороны Российской Федерации предпринимало беспрецедентные усилия для создания законодательной базы по вопросам химического разоружения, внося в Государственную Думу совместно с МИД одно за другим предложения по этой проблеме. В мае и ноябре 1997 г., наконец, были приняты закон «Об уничтожении химического оружия» [6] и закон «О ратификации Конвенции о запрещении разработки, производства, накопления и применения химического оружия и его уничтожении» [7].

Появление этих законодательных актов позволило аппарату УНВ РХБЗ резко активизировать работу по согласованию с местными органами власти мест создания объектов уничтожения и строительства сооружений социальной и инженерной инфраструктуры, не только в интересах предприятий утилизации химического оружия, но и в интересах тех районов, где планировалось создавать такие объекты.

Кроме этого, формированиюу местного населения положительного отношения к проблеме способствовало «Положение о зоне защитных мероприятий, устанавливаемых вокруг объектов хранения и уничтожения ХO» (Постановление Правительства РФ от 24 февраля 1999 г. № 208) [8], поскольку люди, проживающие в этих зонах, получили некоторые социальные льготы. Например, для таких граждан предусматривались консультативно-диагностические обследования в специально созданных для этих целей медицинских центрах. Размеры площадей зон защитных мероприятий для каждого объекта утверждались отдельными распоряжениями правительства.

На исходе XX столетия нами осуществлялся активный поиск необходимых для реализации государственной программы финансовых средств, в том числе и за рубежом. Однако, в целом одобряя разоруженческие идеи России, запад не спешил раскошеливаться. США, например, частично финансировали строительство объекта на арсенале Щучье, но эти затраты несопоставимы с нашими.

Таким образом, к 2000 г. были созданы все условия для выполнения Россией конвенционных обязательств в области химического разоружения, кроме одного, но чрезвычайно важного. Офицеры Управления войск РХБЗ трудились, не жалея себя, пренебрегая зачастую интересами семей и своим здоровьем. Надежной опорой для меня в это время были мои заместители, генерал-лейтенанты Ю.Н. Корякин, В.Н. Орлов, В.И. Холстов, В.И. Евстигнеев, a также офицеры, возглавлявшие управления и отделы. Их усилиями были не только сохранены, но и укреплены войска, осуществлены мероприятия по эвакуации теперь уже из-за рубежей России режимных частей и учреждений, вывезены значительные материальные ценности. Об этом нужно писать не статьи, а книги! Именно в эти тяжкие годы был создан надежный фундамент для решения важнейшей государственной задачи - уничтожения химического оружия. 
В 2000 г. начальник Генерального штаба генерал армии А.И. Квашнин поддержал идею передачи химического оружия из подчинения Министерства обороны Российской Федерации в агентство по боеприпасам. Из состава УНВ РХБЗ было выведено целиком Управление ликвидации химического оружия и значительная часть офицеров других управлений и служб, преобразованных в «Федеральное управление по безопасному хранению и уничтожению химического оружия» с подчинением ему всех арсеналов, учебно-тренировочного центра в Чапаевске и Саратовского училища войск РХБЗ.

Прошло 17 лет и эти люди блестяще завершили ликвидацию миллионов химических боеприпасов, содержащих 40 тыс. т ОВ. Это был героический и смертельно опасный труд. Только профессионал может оценить величие подвига этого коллектива и подчиненных ему частей, осуществивших выполнение программы без единого случая поражения личного со- става и населения. Трудно предположить, как и в какие сроки была бы реализована эта задача, не будь во главе Федерального управления В.П. Капашина, нечеловеческая воля и самоотверженный труд которого непрерывно мобилизовали людей на достижение поставленных целей, а жесткая требовательность, заставлявшая даже нерадивых трудиться на грани своих возможностей, неумолимо продвигала процесс ликвидации химического оружия к победному финишу.

Досрочное выполнение государственной программы сэкономило для страны значительные денежные средства и избавило население обширных территорий, примыкавших к объектам хранения, от серьезных угроз в случае аварий и происшествий на них. И это главный итог 25-летней деятельности УНВ РХБЗ Вооруженных Сил Российской Федерации и Федерального управления БХУХО в области химического разоружения.

Информащия о конфликте интересов

Автор заявляет, что исследования проводились при отсутствии любых научных, коммерческих или финансовых отношений, которые могли бы быть истолкованы как потенциальный конфликт интересов.

Сведения о рецензировании

Статья прошла открытое рецензирование двумя рецензентами, специалистами в данной области. Рецензии находятся в редакции журнала.

Список источников

1. Конвенция о запрещении разработки, производства, накопления и применения химического оружия и о его уничтожении. Париже. 13 января 1993 г. URL: http://www.un.org/ru/documents/decl_conv/ conventions/chemweapons.shtml.

2. О внесении изменения в указ Президента Российской Федерации от 17 февраля 1994 г. № 330 «О порядке привлечения воинских частей и учреждений Вооруженных сил Российской Федерации для проведения мероприятий по реализации международных обязательств России в области химического разоружения" и признании утратившими силу некоторых актов Президента Российской Федерации. Указ Президента РФ от 13.08.1998 № 954.

3. Об организации работ по созданию объекта по уничтожению запасов отравляющих веществ, хранящихся на территории Саратовской области (с изменениями на 8 августа 2003 года № 475). Постановление Правительства Российской Федерации от 30 декабря 1994 года № 1470. URL: http://docs.cntd.ru/ document/783300036.

4. О подготовке Российской Федерации к выполнению международных обязательств в области химического разоружения. Указ Президента РФ от 24 мар- та 1995 г. № 314. Система ГАРАНТ: http://base.garant. ru/1518226/\#ixzz54qQndZYV.

5. Об утверждении Федеральной целевой программы «Уничтожение запасов химического оружия в Российской Федерации». Постановление Правительства РФ от 21 марта 1996 г. № 305 (с изменениями и дополнениями). Система ГАРАНТ: http://base. garant.ru/10108237/\#ixzz54qR7FfCR.

6. Об уничтожении химического оружия. Федеральный закон от 2 мая 1997 г. № 76-Ф3 (с изменениями и дополнениями). Система ГАРАНТ: http://base. garant.ru/2150201/\#ixzz54qRyLeAb.

7. О ратификации Конвенции о запрещении разработки, производства, накопления и применения химического оружия и о его уничтожении. Федеральный закон от 5 ноября 1997 г. № 138-ФЗ. Система ГАPAHT: http://base.garant.ru/12104240/\#ixzz54qSTPScu.

8. Об утверждении Положения о зоне защитных мероприятий, устанавливаемой вокруг объектов по хранению химического оружия и объектов по уничтожению химического оружия. Постановление Правительства РФ от 24 февраля 1999 г. № 208. С изменениями и дополнениями от: 6 июня 2013 г. Система ГАРАНТ: http://base.garant.ru/12114650/\#ixzz54qSqXmiW. 
Об авторе

Федеральное государственное бюджетное учреждение «27 Научный центр» Министерства обороны Российской Федерации. 105005, Российская Федерация, г. Москва, Бригадирский переулок, д. 13.

Петров Станислав Вениаминович. Главный научный сотрудник, д-р техн. наук.

Адрес для переписки: Петров Станислав Вениаминович; 27nc@mil.ru.

\title{
The Start of the State Program of CW Destruction in Russia
}

\author{
S.V. Petrov \\ Federal State Budgetary Establishment \\ "27 Scientific Centre» of the Ministry of Defence of the Russian Federation, \\ Brigadirskii Lane 13, Moscow 105005, Russian Federation
}

The last chemical munition from Russian arsenals of chemical weapons has been destroyed September 22, 2017, at the Kizner facility in Udmurtia. Chemical weapons (CW) destruction started at the times of the demise of the USSR and the change of political formation in the country, followed by the collapse of its economy. Russian Federation Government Decree № 305, «On the Approval of the Special Federal Targeted Program for the Destruction of Chemical Weapons Stockpiles in the Russian Federation» (21 March 1996), became an important milestone in Russia`s fulfilling its international commitments, including its chemical weapons disarmament obligations. Due to certain Soviet scientific and technological advances and thanks to the extraordinary efforts and talent of the experts from the Radiological, Chemical and Biological Defence Troops of the Armed Forces of the Russian Federation, from the Federal Agency for the Safe Storage and Destruction of Chemical Weapons and from several other scientific research organizations, the CW destruction program has been completed three years ahead of schedule. Two-stage process of chemical neutralization, technically adapted to different types and ways of CW stockpiling, have been used for CW destruction. Seven special facilities have been built in Gorny (Saratov region), Kambarka and Kizner (Udmurt Republic), Maradykovsky (Kirov region), Shchuch'ye (Kurgan region), Leonidovka (Penza region) and Pochep (Bryansk region) for this purpose. 40,000 metric tons of CW have been destroyed at these facilities. The implementation of the Federal Targeted Program three years ahead of schedule saved considerable financial resources for the country and saved the population of the regions where $\mathrm{CW}$ stockpiling and destruction facilities have been located, from serious danger in case of any incident or accident.

Keywords: chemical weapons; USSR; convention; destruction; Federal Agency for the Safe Storage and Destruction of Chemical Weapons; NBC Defence; munitions; utilization; complex for the destruction of faulty chemical munitions (KUASI).

For citation: Petrov S.V. The Start of the State Program of CW Destruction in Russia // Journal of NBC Protection Corps. 2018. V. 2. № 1. P. 24-36. 
Conflict of interest statement

The author declares that the research was conducted in the absence of any commercial or financial relationship that could be construed as a potential conflict of interest.

Peer review information

The article has been peer reviewed by two experts in the respective field. Peer reviews are available from the Editorial Board.

\section{References}

1. Convention on the Prohibition of the Development, Production, Stockpiling and Use of Chemical Weapons and on their Destruction. Paris. January 13, 1993. URL: http://www.un.org/ru/documents/ decl_conv/conventions/chemweapons.shtml (in Russian).

2. Changes into the Presidential Decree № 330 (February 17, 1994) «On the participation of military units and establishments of the Armed Forces of the Russian Federation in the operations and arrangements, connected with Russia's fulfilling its international commitments, including its chemical weapons disarmament obligations». Presidential Decree № 954, 13.08.1998 (in Russian).

3. Government Decree № 1470 (December 30, 1994) on the establishment of the CW destruction facility in Saratov region. URL: http://docs.cntd.ru/document/783300036 (in Russian)

4. Presidential Decree № 314 (March 24, 1995) on the preparation of the Russian Federation to fulfilling its international commitments, including its chemical weapons disarmament obligations. GARANT System.
URL: http://base.garant.ru/1518226/\#ixzz54qQndZYV (in Russian).

5. Government Decree № 305 (March 21, 1996) «On the Approval of the Special Federal Targeted Program for the Destruction of Chemical Weapons Stockpiles in the Russian Federation». GARANT System. URL: http://base. garant.ru/10108237/\#ixzz54qR7FfCR (in Russian).

6. CW Destruction. Federal Law № 76-Ф3. May 2, 1997. GARANT System. URL: http://base.garant. ru/2150201/\#ixzz54qRyLeAb (in Russian).

7. Federal Law № 138-Ф3 (November 5, 1997) on the ratification of Chemical Weapons Convention. GARANT System. URL: http://base.garant. ru/12104240/\#ixzz54qSTPScu (in Russian).

8. Government Decree № 208 (February 24, 1999) on the establishment of protective zones around the stockpiling and destruction facilities. Changed June 6, 2013. GARANT System. URL: http://base.garant. ru/12114650/\#ixzz54qSqXmiW (in Russian).

Author

Federal State Budgetary Establishment «27 Scientific Centre» of the Ministry of Defence of the Russian Federation. Brigadirskii Lane 13, Moscow 105005, Russian Federation.

Petrov S.V. Chief Researcher of the Centre. Doctor of Technical Sciences.

Adress: Petrov Stanislav Veniaminovich; 27nc@mil.ru. 